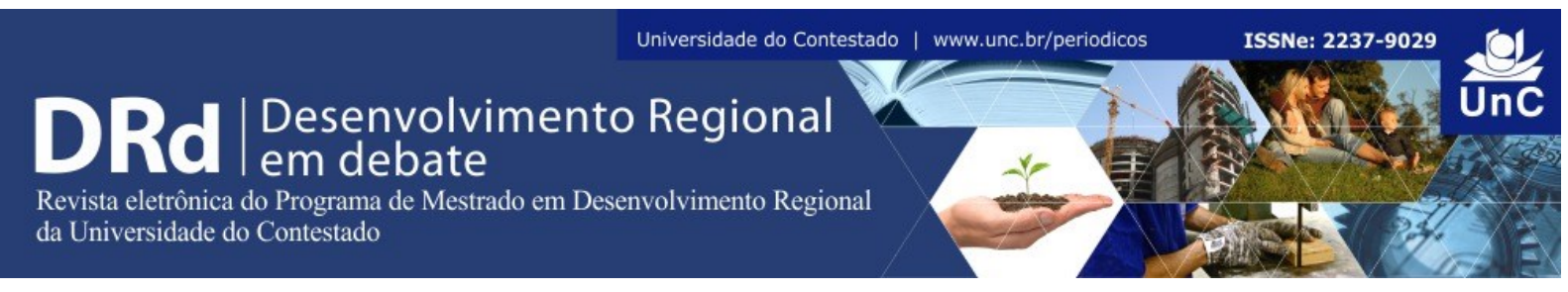

\title{
A REGIÃO TRANSFRONTEIRIÇA DA TRÍPLICE FRONTEIRA E A CONSTRUÇÃO DE UM PROJETO INTEGRADO DE DESENVOLVIMENTO
}

\author{
João Marcos Borges Avelar ${ }^{1}$ \\ Mirian Beatriz Schneider ${ }^{2}$
}

\begin{abstract}
RESUMO
A tríplice fronteira de Foz do Iguaçu, Ciudad Del Este e Puerto Iguazú constitui-se em um importante centro comercial e turístico, permitindo que cidadãos do Brasil, Argentina e Paraguai compartilhem o mesmo território formando uma importante região transfronteiriça. Cada uma das cidades possui um Conselho de Desenvolvimento Econômico e Social que atua na construção de um Projeto Integrado de Desenvolvimento, estabelecendo parcerias com entidades e empresas da região. A consolidação desse projeto depende da ação conjunta dessas entidades, da legislação de cada país envolvido, e do comprometimento dos governos municipais com o desenvolvimento regional. O grande desafio da construção de um Projeto Integrado de Desenvolvimento Regional está em promover a cooperação entre os agentes locais, o setor produtivo e os governos locais de forma a resolver os problemas comuns existentes. O objetivo deste trabalho é o de identificar se há no local um Projeto Integrado de Desenvolvimento e como as lideranças políticas e sociais atuam nesta direção. Foi utilizada a metodologia do Hexágono do Desenvolvimento Regional e a aplicação de questionários semiestruturados para lideranças das três cidades. Os resultados obtidos indicam que embora haja um trabalho consistente dos atores locais, ainda não foi possível consolidar um Projeto de Desenvolvimento Integrado para a tríplice fronteira.
\end{abstract}

Palavras-chave: Tríplice fronteira. Região Transfronteiriça. Desenvolvimento Regional.

\footnotetext{
${ }^{1}$ Diretor da Universidade Estadual do Paraná - Unespar campus de Campo Mourão, professor do Colegiado de Administração. Mestre em Desenvolvimento Econômico pela UFPR e Doutor em Desenvolvimento Regional pela UNIOESTE. Universidade Estadual do Paraná. Paraná. Brasil. E-mail: jmavelar@yahoo.com.br

${ }^{2}$ Professora Associada do Programa de Pós-Graduação em Desenvolvimento Regional e Agronegócio, do Programa de Pós-Graduação em Economia e do Colegiado do Curso de Ciências Econômicas da UNIOESTE. Pesquisadora do GEPEC. Universidade Estadual do Oeste do Paraná. Paraná. Brasil. E-mail: jmavelar@yahoo.com.br
}

DRd - Desenvolvimento Regional em debate (ISSNe 2237-9029)

v. 9, p. 179-203, 2019. 


\title{
THE CROSS-BORDER REGION OF THE FRONTIER TRIPLE AND THE CONSTRUCTION OF AN INTEGRATED DEVELOPMENT PROJECT
}

\begin{abstract}
The triple border of Foz do Iguaçu, Ciudad Del Este and Puerto Iguazú is an important commercial and tourist center, allowing citizens of Brazil, Argentina and Paraguay to share the same territory forming an important transboundary region. Each one of the cities has an Economic and Social Development Council that works to build an Integrated Development Project, establishing partnerships with entities and companies of region. The consolidation of this project depends on the joint action of these entities, the legislation of each involved country and the commitment of municipal governments to regional development. The great challenge of build an Integrated Regional Development Project is promote an cooperation between local agents, the productive sector and local governments in order to solve common problems. The objective of this work is to identify if there is an Integrated Development Project and how the political and social leaders act in this direction. The Hexagon methodology of the Regional Development was used and the application of semi-structured questionnaires for leaders of the three cities. The results indicate that although there is a consistent work of the local agents, it has not yet been possible to consolidate an Integrated Development Project for the triple border.
\end{abstract}

Keywords: Triple border. Cross-Border Region. Regional development.

\section{INTRODUÇÃO}

A tríplice fronteira de Foz do Iguaçu, Ciudad del Este e Puerto Iguazú é um local conhecido internacionalmente pelos seus atrativos turísticos, belezas naturais e por seu grande potencial comercial. Consiste em uma região que embora exista uma fronteira legalmente demarcada, os cidadãos brasileiros, argentinos e paraguaios compartilham o mesmo território nos principais pontos turísticos e comerciais das três cidades, indicando a existência de uma região transfronteiriça. A consolidação da região transfronteiriça depende de ações conjuntas entre as três cidades e das políticas públicas para o desenvolvimento do local.

Conforme Brasil (2015), nas últimas décadas houve um crescimento do debate sobre o papel das regiões e dos governos locais na promoção do seu próprio desenvolvimento, surgindo a necessidade da criação de estratégias regionais para promoção do desenvolvimento e para melhor definir qual é o papel do poder local na promoção desse processo, tendo como objetivo minimizar as desigualdades sociais e outras situações que agravam as disparidades inter-regionais. O debate em torno do poder local e sobre os avanços da organização local assume relevância na busca de sinergias para a promoção do desenvolvimento de um determinado território, embora, ainda prevaleça a crença de que a mudança necessária à promoção de uma melhor qualidade de vida da população venha por ações engendradas exclusivamente pelo Estado. É, portanto, um debate cuja perspectiva da mobilização em prol do desenvolvimento opõe-se a uma visão centralizada na esfera do governo nacional, sendo que o protagonismo do poder local requer uma gestão das questões locais e regionais de maneira a encontrar soluções adequadas à realidade e às potencialidades do território. Isso significa a criação de uma capacidade de autotransformação econômica e social no município

DRd - Desenvolvimento Regional em debate (ISSNe 2237-9029) 
ou na região. É um modelo de gestão em que as organizações comunitárias e outros atores são incentivadas a perderem o medo de inovar e de mexer nas hierarquias tradicionais de decisão, e assim, encontrem respostas para as suas necessidades por meio da cooperação e articulação de atores sociais.

Sachs (1986), comenta que a participação efetiva das populações locais na realização das estratégias de desenvolvimento passa pela identificação das potencialidades produtivas, pela organização do esforço coletivo, bem como da definição das necessidades existentes na localidade de forma clara. Para participar do planejamento de desenvolvimento é indispensável que essa população seja sensibilizada sobre os aspectos necessários ao desenvolvimento e que lhes seja garantido o acesso à informação de qualidade. É, portanto, um estilo de desenvolvimento que necessita da articulação de um poder local e regional capaz de superar os particularismos setoriais e que esteja preocupado com todas as facetas do desenvolvimento das diferentes ações empreendidas.

A construção de um projeto integrado de desenvolvimento precisa encontrar mecanismos para superar dificuldades típicas de empreendimentos isolados, produzindo espaços cooperativos entre o setor produtivo e as instituições parceiras. Isso pode permitir reforçar o capital social de uma região e a construção de redes de reciprocidade e solidariedade organizadas. Essa parceria precisa estar voltada para as reais necessidades do território e dispostas a estabelecer ações conjuntas para resolver os problemas existentes. Um exemplo de parcerias que podem surtir resultados positivos são as parcerias com universidades locais, pois estas tendem a reunir condições técnicas e humanas de desenvolver projetos de pesquisa e extensão aplicados à realidade regional.

Conforme Polon (2014), o Brasil possui nove tríplices fronteiras, porém, a que tem maior expressividade em razão das suas populações e de sua urbanização e atividades econômicas é a tríplice fronteira entre Foz do Iguaçu, Ciudad del Este e Puerto Iguazú. Para Myskiw (2011), o município de Foz do Iguaçu localiza-se no extremo Oeste do Estado do Paraná e é conhecido mundialmente pelo turismo e pela Usina Hidrelétrica de Itaipu. Até o ano de 1910, Foz do Iguaçu era uma Colônia Militar, que foi criada em 1889, sendo elevada a município em 1914 e reconhecida pelo nome de Foz de Iguaçu em 1918. A constituição da Colônia Militar teve como objetivos interesses relacionados ao desenvolvimento comercial, industrial e político da região, bem como o seu povoamento e integração com outras regiões do Estado do Paraná e do Brasil. Um outro objetivo da Colônia Militar foi promover a proteção da fronteira contra invasões na época de paraguaios e argentinos.

De acordo com Polon (2014), outros fatores que contribuíram para o desenvolvimento da região foram a criação do Parque Nacional do Iguaçu em 1939, que potencializou as atividades de turismo; a construção da Ponte da Amizade, que permitiu a intensificação do comércio e dos contatos entre os lados brasileiro e o paraguaio; e a construção da Hidrelétrica de Itaipu iniciada em 1974. Essa construção atraiu milhares de pessoas para a região e acabou gerando vários tipos de atividades comerciais, tanto formais como informais. Com o fim das obras da usina, houve um grande desemprego na cidade (aproximadamente 15.000 desempregados em 1984), resultando graves problemas sociais, fazendo aumentar a criminalidade e o subemprego, a proliferação de moradias precárias, falta de planejamento urbano e aumento dos índices de mortalidade infantil.

DRd - Desenvolvimento Regional em debate (ISSNe 2237-9029) 
De acordo com Catta (2002), embora Foz do Iguaçu tenha desenvolvido atrativos turísticos, redes hoteleiras e outros serviços para a demanda dos visitantes, na verdade, foram as compras no Paraguai que atraíram os turistas ao local. A década de 1990 foi marcada por um grande contingente de "sacoleiros" (pessoas que compravam em pequenas quantidades para revender em suas cidades de origem) no comércio dessa fronteira. Esse grupo sofreu discriminação e pressão das classes dominantes e do poder público por serem considerados um entrave ao bem-estar da cidade de Foz do Iguaçu.

Segundo Polon (2014), o município de Ciudad del Este foi fundado em 1957, embora nessa época tenha recebido o nome de Puerto Flor de Liz, e depois, de Puerto Presidente Strossner. Em 1989, recebeu a denominação atual. A cidade está localizada no extremo leste do Paraguai e constitui-se em um dos maiores centros comerciais do mundo. De acordo com Cury (2010), é a segunda cidade mais importante do Paraguai, perdendo apenas para a capital Assunção. As fronteiras entre as duas cidades (Foz do Iguaçu e Ciudad del Este) são quase imperceptíveis no cotidiano da região, que se tornou um dos principais pontos comerciais do mundo.

Para Cardin (2010), a construção da usina de Itaipu, o desenvolvimento da rota comercial em Foz do Iguaçu (em decorrências dos produtos paraguaios) e o crescimento do comércio foram os fatores que contribuíram para um considerável aumento populacional na Ciudad del Este, que indiscutivelmente está conectada aos circuitos globais da economia mundial. Conforme Haesbaert (2013), a cidade estabeleceu laços oficiais com Taiwan e permitiu o estabelecimento de um distrito industrial em sua periferia. Ciudad del Este também é associada a ações ilegais, tais como lavagem de dinheiro, narcotráfico, tráfico de pessoas e contrabando de mercadorias, gerando conflitos entre as máfias que lá atuam.

De acordo com Polon (2014), as fronteiras sempre estiveram relacionadas ao poder, e, a ocupação da fronteira Brasil/Paraguai seguiu esse pressuposto. Nas décadas de 1960 e 1970, a construção de Itaipu, a marcha para o Oeste no Estado do Paraná e a marcha para o Leste, ocorrida no lado paraguaio, facilitou o ingresso de brasileiros no território paraguaio. Isso ocorreu pelo fato de que o governo paraguaio precisava de investimentos para promover seu desenvolvimento e o governo brasileiro, devido ao processo de modernização em que vivia, precisava expandir os espaços exploráveis. A facilidade de obter terras no lado paraguaio atraiu muitos brasileiros para o outro lado da fronteira. Dessa migração surgem os chamados "brasiguaios" e também os conflitos no ambiente transfronteiriço. A denominação de brasiguaios é dada às pessoas que apresentam dificuldades em se saber se pertencem ao lado brasileiro ou paraguaio, sendo na maioria das vezes tratados de forma marginalizada e excluídos de seus direitos de cidadãos tanto de um país como de outro. Essas pessoas recebem influências culturais e sociais tanto do Brasil como do Paraguai, tendo educação formal em seu país, porém convivendo com programas televisivos, emissoras de rádio, músicas e com a própria língua falada do outro país e mesmo o uso da moeda de um país em outro.

Conforme Polon (2014), Puerto Iguazú (da província de Misiones) está localizada a $18 \mathrm{~km}$ da área em Foz do Iguaçu sendo possível o acesso entre as duas cidades por meio da Ponte Internacional Tancredo Neves que une as rodovias RN 12 e a BR-469. A população de Puerto Iguazú é de aproximadamente 80.000 habitantes, sendo, portanto, a menor das cidades que compõem a tríplice fronteira. O turismo é a principal atividade econômica da cidade, com isso, as hotelarias e o comércio são as principais fontes de renda de seus habitantes. A cidade possui um importante centro comercial próximo à Ponte Internacional, o Duty Free Shop. No

DRd - Desenvolvimento Regional em debate (ISSNe 2237-9029) 
centro, há um comércio estruturado, com bares, cassinos, restaurantes, lojas de roupas, lojas de artigos de desporto, discotecas, bancos, redes hoteleiras, entre outros. Além da Cataratas do Iguaçu, existem alguns atrativos turísticos importantes, como o Parque Natural Municipal Luís Honório Rolón, a feira artesanal, o Museu M'bororé, o Museu de Imagens da Selva, o Centro de Reabilitação para aves Guira Oga, um Cassino Internacional, o Complexo La Aripuca e o Porto. Na parte da fronteira que compreende as cidades de Foz do Iguaçu, Puerto Iguazú e Ciudad del Este, as relações transfronteiriças vão muito além das práticas comerciais analisadas no âmbito da fronteira, pois as mercadorias que são trazidas do Paraguai para o Brasil são destinadas a outras regiões brasileiras e até mesmo para outros países. Os limites das fronteiras são de difícil identificação, uma vez que os deslocamentos correm tanto por via terrestre, como aérea e por navegação. A Figura 1 mostra a localização da tríplice fronteira.

Figura 1 - Tríplice Fronteira

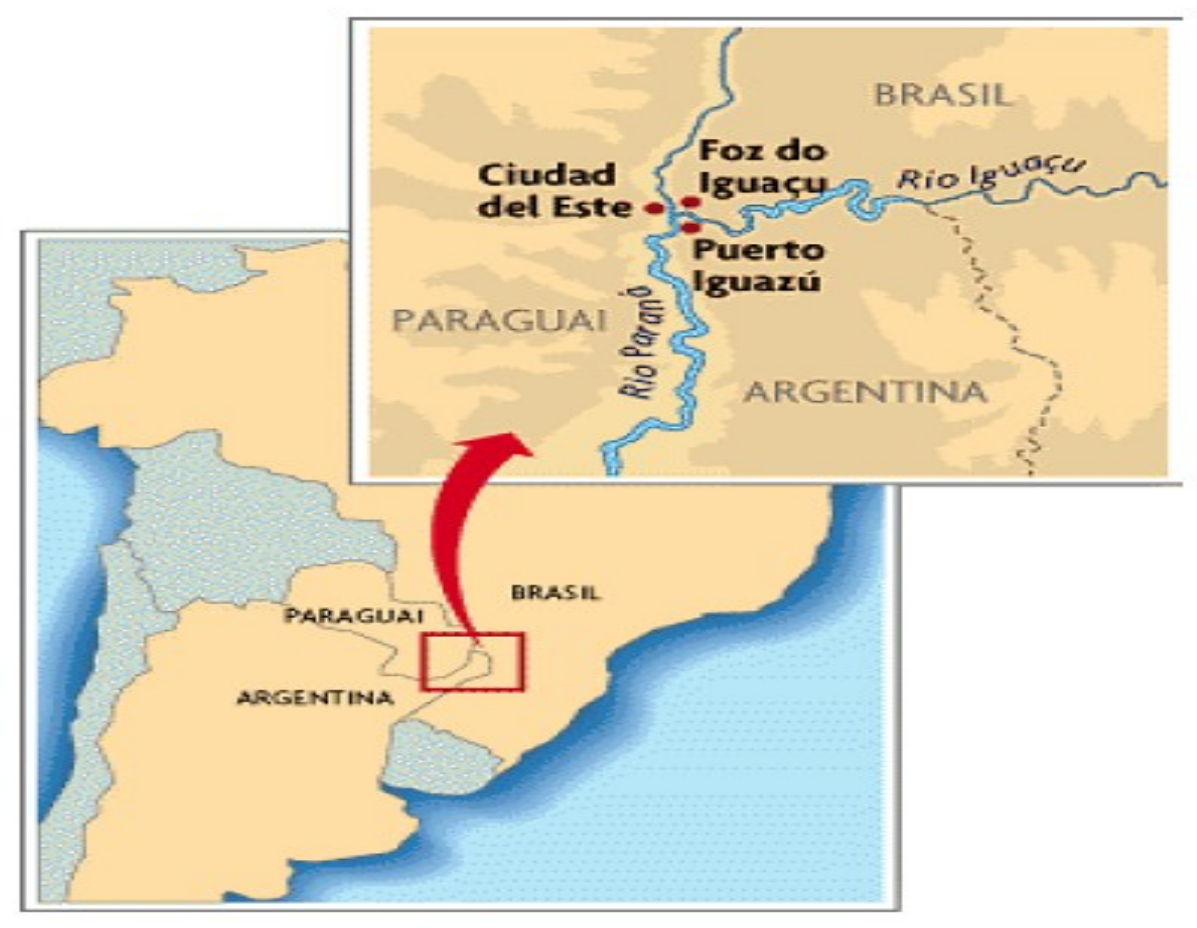

Fonte: Polon (2014).

A Tríplice Fronteira, em questão, possui dinâmicas econômica e social diferenciadas de outras regiões do Brasil, o que torna ainda mais difícil a realização de ações que possam promover o seu desenvolvimento regional. As limitações jurídicas e políticas tornam-se entraves para o desenvolvimento, sendo necessário que um conjunto de políticas públicas sejam efetivadas para que haja melhoria na qualidade de vida das pessoas que residem nessas localidades. Como se trata de localidades que estão atreladas às normas e legislação de cada país, promover ações conjuntas requer o estabelecimento de acordos internacionais que sejam benéficos a todos os envolvidos. Isso demanda de capacidade técnica e de vontade política para realmente encontrar soluções para a população, principalmente para as camadas sociais mais fragilizadas. 
As políticas públicas dirigidas às fronteiras internacionais encontram como principais obstáculos interesses, leis e estruturas institucionais diferentes, tornando o processo altamente complexo, pois busca possibilidades de integração ao mesmo tempo que cria problemas nas condições de uso e ocupação do território. Portanto, a Região Transfronteiriça de Foz do Iguaçu possui limitações jurídicas e políticas que se tornam entraves para o desenvolvimento. É uma localidade que está atrelada às normas e legislação de cada país, e portanto, para que sejam realizadas ações conjuntas depende de acordos internacionais. Esses acordos apenas se consolidam diante de um cenário de vontade política e da formação de uma equipe técnica competente e que esteja comprometida em encontrar soluções para os problemas da população, pois o desenvolvimento regional implica em ações coordenadas da governança local e dos atores sociais de cada região, promovendo a participação da sociedade civil e a aproximação com instituições de ensino, de pesquisa e de extensão, como universidades, institutos e associações.

Na região em estudo, o capital financeiro flui de um país para outro com facilidade e agilidade. Isso ocorre tanto no aspecto legal como no ilegal, considerando que a região também está propensa à ação do crime organizado. Também se observa situações de exclusão social, caracterizada pelo desemprego, subemprego dos trabalhadores que vivem o cotidiano da fronteira, inclusive dos sacoleiros e laranjas que sobrevivem da compra, venda e transporte de mercadorias. Um outro ponto que aparece como entrave ao desenvolvimento é a uniformização das práticas culturais, que acaba favorecendo o predomínio da cultura brasileira sobre as demais cidades. Isso se concretiza por meio da mídia brasileira. Dadas as características da região, o desenvolvimento endógeno é uma das alternativas para a alavancagem do desenvolvimento. A região possui a capacidade de envolver os agentes locais e de promover ações concretas e focadas em promover o desenvolvimento, promovendo ações empreendedoras e valorizando as potencialidades locais. $\mathrm{O}$ Estado tem um papel fundamental nesse processo pois precisa motivar e criar estruturas para que haja o engajamento dos agentes.

É necessária uma legislação que estabeleça para a região normas diferentes das que são praticadas em outros pontos da fronteira brasileira, devido às particularidades do local. Isso poderia ser sanado com a criação de um Estatuto da Fronteira, como já existe para a fronteira entre Brasil e Uruguai. A elaboração desse Estatuto ou de outra legislação que objetive regulamentar o uso compartilhado desse território pode melhorar as relações produtivas e comerciais entre as três cidades.

Para Haesbaert (2004), existem vários tipos coexistentes de territórios no mundo contemporâneo que buscam atender aos aspectos políticos, econômicos, culturais e naturais de um espaço. Um mesmo espaço, como por exemplo, um território natural como uma praça, pode se destinar, ao lazer durante algum período do dia e durante a noite ser destinada a apresentações de espetáculos musicais. Esse mesmo espaço pode, ainda, ser utilizado para manifestações políticas, e durante alguns dias da semana abrigar feiras livres. Fisicamente, continua sendo o mesmo espaço, mas assume funções diferentes em cada situação, sendo denominado por Haesbaert como território-zona.

Uma outra concepção, defendida por Haesbaert é o território-rede, baseada no entendimento de um território articulado e conectado, comprometido com questões de ordenamento, controle e gestão do espaço. Isso leva ao conceito de um território como uma 
experiência integrada do espaço, necessitando de uma estruturação em rede que conecta diferentes pontos ou áreas.

Portanto, há indicativos de que no mundo contemporâneo há o predomínio da lógica do domínio do território-rede, que espacialmente podem ser descontínuos, porém são conectados e articulados entre si, superando o predomínio anterior da lógica dos "territórioszona", que não admitiam sobreposições. Segundo Haesbaert (2004), existem quatro dimensões com que o território é focalizado, ou seja, as dimensões: política, cultural, econômica e natural.

Sob a ótica dos Estados brasileiro, argentino e paraguaio, o local é um território-zona, pois cada cidade tem seu espaço juridicamente demarcado, mas para os moradores, o local é entendido como um território-rede, pois as pessoas, as mercadorias e o capital circulam na região como se fizessem parte de um mesmo país. Isso serve para ilustrar como é necessária uma regulamentação que discipline essas situações e contribua para o desenvolvimento e não para o fortalecimento de entraves econômicos e sociais.

O conceito de região transfronteiriça adotado nesta pesquisa está relacionado à existência de uma linha que separa os territórios envolvidos, ou seja, a fronteira legal entre Brasil e Paraguai e, Brasil e Argentina. Os espaços que compreendem os locais de circulação de pessoas, mercadorias e serviços ao longo dessa linha de fronteira, que efetivamente são os espaços geográficos que estão no centro comercial de Foz do Iguaçu e nas proximidades da Ponte da Amizade, na área comercial de Ciudad del Este e no Centro comercial de Puerto Iguazú, são portanto, o que nesta pesquisa classificamos como região transfronteiriça.

O objetivo do trabalho é analisar, sob a perspectiva da Metodologia do Hexágono do Desenvolvimento Regional, se há na região da tríplice fronteira de Foz do Iguaçu, Ciudad del Este e Puerto Iguazú um projeto comum de desenvolvimento regional. Analisou-se o período de 2007 a 2015, em razão das principais políticas públicas brasileiras para as regiões de fronteiras terem sido implementadas neste período.

O estudo está dividido em 4 seções, sendo a primeira esta introdução; a seção 2 descreve a metodologia utilizada na pesquisa; a terceira seção apresenta informações sobre as perspectivas de se consolidar um projeto de desenvolvimento integrado na tríplice fronteira de Foz do Iguaçu, Ciudad del Este e Puerto Iguazú, bem como os resultados obtidos por meio de entrevistas realizadas com lideranças das três cidades; e, por fim, ressaltam-se as considerações finais do estudo.

\section{METODOLOGIA}

Conforme Rolim (2004), a base metodológica para a análise de uma região transfronteiriça está nos procedimentos para entender como ela funciona internamente, como se relaciona com outras regiões e países, quais são os empecilhos à livre movimentação e que tipo de espaço econômico pode ser produzido e concretizado nesses locais. Uma ferramenta disponível para tanto é o esquema denominando Hexágono do Desenvolvimento Regional, desenvolvido por Sérgio Boisier. Refere-se aos seis elementos sem os quais dificilmente uma 
região se desenvolverá. A presença desses elementos indicará o que irá acontecer a uma região a médio e a longo prazo.

O Hexágono do Desenvolvimento Regional constitui-se em um esquema analítico adequado para um conhecimento mais aprofundado da região tendo como perspectiva a elaboração de estratégias de desenvolvimento. É uma ferramenta, que segundo Rolim (2004), pode ser utilizada na análise de uma região transfronteiriça.

Com base nos estudos de Boisier (1996), os elementos do Hexágono do Desenvolvimento Regional são:

a) Atores: os atores e/ou agentes do desenvolvimento podem ser identificados por categorias, sendo classificados por natureza individual, natureza corporativa e natureza coletiva. Os atores individuais são os membros da sociedade civil que ocupam posições de poder e de influência na região. Identificá-los torna-se algo de grande importância para se conhecer a estrutura de poder regional e para se iniciar um processo participativo de preparação de um projeto integrado. Os atores corporativos são os sindicatos, agrupamentos empresariais, estudantis, e outros grupos organizados. São mais fáceis de identificar por possuírem personalidade jurídica e a sua legalidade está regulamentada pelo Estado. Os atores coletivos são os movimentos sociais regionais. É importante determinar o ethos de cada categoria de ator. Isso significa entender o conjunto de características que orientam a sua conduta, destacando os elementos comportamentais que prevalecem nos grupos e que, por exemplo, podem indicar uma certa lealdade ao lugar ou a existência de uma conduta que possa falar da existência de empresários regionais. Portanto, é preciso descobrir a regionalidade das demandas dos diferentes setores e sua capacidade de articular lógicas coletivas.

b) Cultura: o uso do termo cultura em relação ao desenvolvimento está relacionado a uma cultura do desenvolvimento e não a acepção mais geral do termo, ligada a uma cosmovisão e a uma ética ou a acepção restrita de conhecimento. A cultura do desenvolvimento se manifesta de duas maneiras extremas: a cultura competitiva/individualista ou a cultura cooperativa/solidária. A primeira é capaz de gerar crescimento, mas sem capacidade de gerar um verdadeiro desenvolvimento. A segunda é capaz de gerar equidade sem crescimento. É importante descobrir a forma em que ambos os padrões culturais estejam combinando, para que ocorra a combinação microeconômica e meso-social da cooperação e da concorrência. Também importa pesquisar a capacidade da cultura do lugar (nesse contexto, o termo readquire sua acepção tradicional) para produzir autorreferência, que é a identificação da sociedade com seu próprio território e a capacidade dessa cultura dominante de introduzir códigos referenciais nas mensagens de autoidentificação territorial.

c) Recursos: para que ocorra o desenvolvimento, a região necessariamente precisa contar com: 1) recursos materiais, que são os recursos naturais existentes, equipamento de infraestrutura e recursos de capital; 2) recursos humanos, considerando a quantidade, qualidade dos mesmos, vinculação regional e contemporaneidade; 3) recursos psicossociais, que são associados a questões como a autoconfiança coletiva, perseverança, a vontade coletiva, o consenso, etc.; 4) os recursos de conhecimento.

d) Instituições: o que interessa no exame da institucionalidade regional não é uma pura e simples listagem das instituições públicas e privadas existentes na região e sim avaliar 
em que medida as instituições são flexíveis (como se ajustam à realidade instável do ambiente), velozes (como entram e saem de acordos e de redes e aproveitam oportunidades), inteligentes (capacidade de aprender e capacidade de estabelecer articulações com outras instituições) e virtuais (condição para se proceder a operações ad hoc e para se configurar arranjos estratégicos). As instituições regionais estão envolvidas nos custos de transação. Isso se transforma numa facilidade para a formação da sinergia indispensável ao desenvolvimento endógeno nas regiões nas quais os custos de transação são menores. Em locais assim, os agentes e atores compartilham os mesmos códigos culturais, e o mesmo sistema jurídico e um conjunto de relações. Esse ambiente contribui para o surgimento da mescla cultural cooperação/concorrência.

e) Procedimentos: ao tratar sobre os procedimentos, Boisier (1996), cita que instituições além das características anteriormente descritas, também precisam de procedimentos adequados, sendo que o procedimento mais importante se refere à natureza da gestão do governo territorial. O termo governo, neste caso, deve ser usado em seu sentido mais próximo da ciência da política, sendo um conjunto de ações que representam o exercício da autoridade, a liderança e a capacidade de tomada de decisões. Portanto, vai muito além do entendimento de gestão de governo com o uso de tecnologias e sistemas de informação.

Os procedimentos administrativos (que se referem às ações cotidianas do governo e a prestação de serviços para a comunidade), o manejo orçamentário, a administração dos recursos humanos, a gestão de projetos de investimento e as relações públicas são componentes essenciais de uma boa administração. Também se destaca a crescente importância do manejo da informação com o objetivo de gerar conhecimento e difundi-lo de maneira massiva e seletiva, sintonizados com a modernidade. Esse é um grande desafio de procedimentos para as organizações que fazem parte de um mapa institucional territorial.

Esses elementos interagem de um modo denso ou difuso, de forma aleatória ou então de uma forma inteligente e estruturada. O desenvolvimento resultará apenas de uma interação densa e inteligentemente articulada, mediante um projeto coletivo ou um projeto político regional. Do contrário, não se terá senão uma caixa preta, cujo conteúdo e funcionamento se desconhece (BOISIER, 1996, p. 133).

A Figura 2 demonstra as vértices do Hexágono do Desenvolvimento Regional. 
Figura 2 - Hexágono do Desenvolvimento Regional

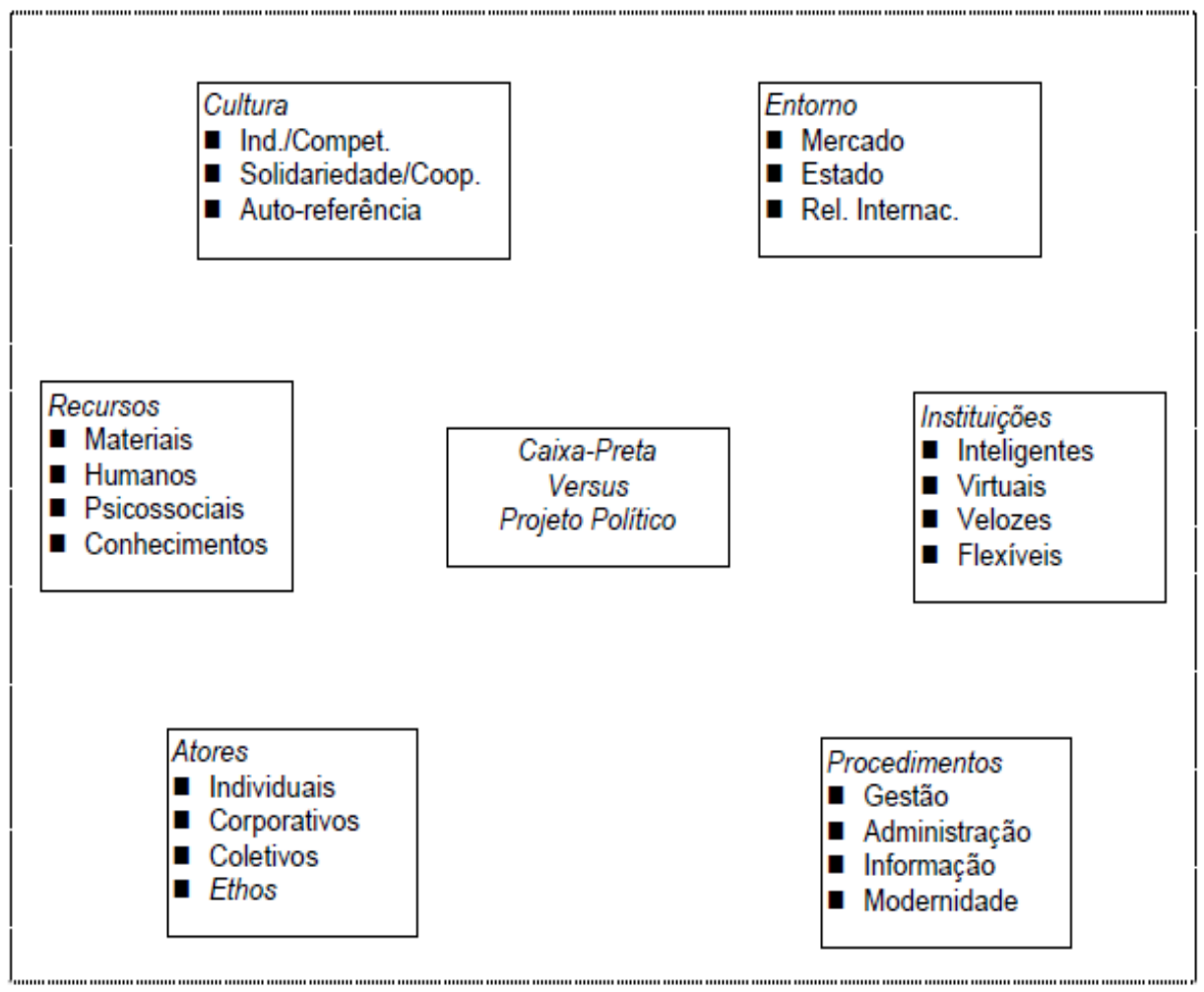

Fonte: Boisier (1996, p. 136).

Na região em análise, o papel do Estado é de grande importância para alavancar o desenvolvimento e promover a articulação entre as cidades, pois, por se tratar de uma tríplice fronteira, todas as ações realizadas num território podem influenciar o outro lado da fronteira. A política econômica adotada pelo Brasil, pelo Paraguai ou pela Argentina tendem a influenciar as atividades econômicas das cidades estudadas. Contudo, o Estado ainda não conseguiu desenvolver este papel com êxito.

Por intermédio da metodologia de análise de regiões proposta pelo Hexágono do Desenvolvimento Regional discutiu-se a existência de um projeto de desenvolvimento articulado na tríplice fronteira, ou se há no local apenas, como cita Boisier (1996), uma caixa preta cujo conteúdo e funcionamento se desconhece.

Um trabalho de campo foi realizado para evidenciar quais vértices do hexágono são contempladas na região e se há uma vontade coletiva e consensual entre as cidades para um projeto de desenvolvimento integrado. O trabalho de campo foi realizado com a aplicação de entrevistas com o gerente da unidade do Sebrae de Foz do Iguaçu e com lideranças que realizam trabalhos relacionados ao desenvolvimento na faixa de fronteira. Na pesquisa foram também realizadas entrevistas semiestruturadas com membros do Conselho de Desenvolvimento Econômico e Social de Foz do Iguaçu (Codefoz) no Brasil; Conselho de Desenvolvimento Econômico e Social de Ciudad del Este (Codeleste) no Paraguai; Conselho de Desenvolvimento Econômico e Social de Puerto Iguazú (Codespi) na Argentina; representantes sindicais; diretores das associações comerciais e industriais de Foz do Iguaçu; representante da Secretaria Municipal de Trabalho, Desenvolvimento Socioeconômico, 
Indústria e Comércio de Foz do Iguaçu; dirigente do Serviço Brasileiro de Apoio à Micro e Pequenas Empresas (Sebrae) de Foz do Iguaçu; e, membros da equipe de Desenvolvimento Territorial do Parque Tecnológico Itaipu (PTI). A realização das entrevistas permitiu analisar os efeitos das políticas públicas do Brasil para Ciudad del Este e Puerto Iguazú e se as ações desenvolvidas contribuíram para a criação de um projeto comum de desenvolvimento para a região em estudo.

O questionário foi composto por 22 perguntas que contribuíram para reunir informações sobre os principais atores individuais, coletivos e corporativos presentes na região, como eles influenciam a tomada de decisões e quais as principais características que orientam a conduta desses atores. Sua aplicação também permitiu identificar se no local predomina a cultura competitiva/individualista ou a cultura cooperativa/solidária.

As entrevistas permitiram também identificar os recursos humanos, materiais, psicossociais e de conhecimento existentes na tríplice fronteira e como esses recursos se articulam com as instituições existentes e se essas instituições possuem procedimentos adequados em termos de procedimentos administrativos e de gestão do território. Por último foi identificado como é a relação das instituições da região com seu entorno (tudo o que é externo à região e é configurado pela multiplicidade de organismos, sobre os quais a região tem a capacidade de influência, mas não tem controle) e as principais modalidades e padrão geográfico do comércio da região.

As informações obtidas com a aplicação dos questionários foram analisadas sob a ótica da Metodologia do Hexágono do Desenvolvimento regional e foram agrupadas de acordo com a similaridade das respostas, permitindo melhor compreender o comportamento dos agentes locais e da sua percepção do desenvolvimento da região.

\section{A CONSTRUÇÃO DE UM PROJETO INTEGRADO DE DESENVOLVIMENTO NA TRÍPLICE FRONTEIRA}

Para Moura Filho (2010), as dimensões cultural e natural revelam-se de suma importância para a identificação da produção de territorialidades. Isso deriva da apropriação ou valorização simbólica de um grupo e seu espaço, principalmente quando esse espaço é composto por fronteiras de estados nacionais. A importância de tais concepções é pertinente aos estudos das fronteiras, uma vez que as fronteiras entre os estados nacionais são vistas pelos governos centrais de cada país como territórios-zona para efeitos de ordenamento territorial. Porém, para as populações locais e para o capital transnacional, a concepção da fronteira é a de territórios-rede, pois para estes grupos as ações por eles desenvolvidas referem-se à estratégia de subsistência e de sobrevivência do local em que vivem. Milton Santos ao tratar do assunto cita que "é o uso do território, e não o território em si mesmo, que faz dele objeto da análise social" (SANTOS, 2006, p. 15).

Para Santos (1978), o território não pode ser entendido como apenas uma área delimitada e constituída pelas relações de poder do Estado. Muito além disso, é preciso considerar as diferentes formas de enfocar o seu uso para não engessar a sua compreensão e tornar possível uma análise que leve em consideração os atores e as relações sociais 
envolvidas. Em outras palavras, as relações de poder existentes em um território podem afetálo e envolver uma gama muito grande de atores que territorializam suas ações com o passar do tempo, diversificando as relações sociais num jogo de poder cada vez mais complexo.

De acordo com Santos (1985), o território é percebido como um recorte espacial, ou seja, o território está contido no espaço e o espaço no território, num movimento dialético, e, é no território que se reproduzem as atividades e culturas da população que vive em um determinado ambiente.

Na Região Transfronteiriça de Foz do Iguaçu, embora cada país possua seu território, há o compartilhamento deste, surgindo um espaço geográfico. Conforme Santos (1978), o conceito de espaço está relacionado às relações sociais do passado e do presente, bem como com as suas relações com os processos e funções existentes numa sociedade, sendo que sua evolução nasce do movimento da própria sociedade por meio de uma práxis coletiva. Assim, o espaço é uma instância social que tende a reproduzir-se conforme à organização feita pelo homem, mas que é também uma forma resultante da interação de diferentes variáveis. Em síntese, o espaço social corresponde ao espaço humano, que pode ser entendido como o lugar onde as pessoas moram, trabalham e vivem.

Segundo Santos (1985), o espaço é produto da organização da sociedade e é entendido como reflexo da sociedade global. Os elementos do espaço são as pessoas, as empresas, as instituições, o meio ecológico e as infraestruturas. Cada um desses elementos cumpre um papel específico na construção do espaço social e cada momento histórico muda o seu papel, assumindo uma nova posição no sistema espacial.

Em Santos (1996), há a defesa da ideia de que o espaço contém o território modelado, configurado; o território, além do aspecto natural da geografia de um determinado local, envolve também às intervenções dos homens, como construções, estradas cidades e demais obras realizadas pela sociedade.

Percebe-se, portanto, que falar sobre espaço e território não é algo simples. A complexidade está relacionada não apenas às situações do clima, relevo ou da própria paisagem que constitui seu ambiente físico, mas principalmente dos aspectos sociais e culturais que estão presentes na sua ocupação. Tratando-se de regiões transfronteiriças, o nível do desenvolvimento econômico e social destes locais será fundamental para a qualidade de vida das pessoas e para o estabelecimento de situações sociais positivas ou negativas dentro de um dado território.

Nas regiões de fronteiras, e em especial, na Tríplice Fronteira de Foz do Iguaçu, Ciudad del Este e Puerto Iguazú, essas relações oriundas da ocupação do espaço criaram um cenário próprio.

Ao tratar sobre a faixa de fronteira, Matos (1990), cita que os limites entre os países são marcados por uma faixa de transição. Nesses locais, os valores culturais, religiosos, ideológicos, a raça e a própria língua e as transações comerciais acabam se misturando, podendo ser caracterizados como regiões de endosmose cultural. O convívio harmonioso dessa interpenetração dos lados da fronteira é pacífico quando se trata de estados amigos, como é o caso da tríplice fronteira em análise, e conturbada ou proibida quando se trata de estados rivais. 
Para Correa (2000), o termo região, que é usado tanto por leigos como por pesquisadores, está ligado à noção fundamental de diferenciação de área, concordando que o planeta Terra é constituído por áreas diferentes entre si.

O conceito de região tem sido usado para fins de ação e controle, decorrente da prática política e econômica de uma sociedade de classes, marcada pelas divisões regionais e pelas ações de controle sobre territórios conquistados ou sob a dependência político-administrativa e econômica de uma classe dominante. Uma região para fins de ação e controle, considera o conceito de região natural e o de região geográfica. A ação e controle sobre uma determinada área objetiva a reprodução da sociedade de classes, que se localiza fora ou no interior da área submetida à divisão regional. Nesta concepção, o Estado, surge dentro do modo de produção dominante como o maior agente da regionalização.

Moura Filho (2010), por sua vez, cita que a região não é apenas uma unidade territorial distinta por características físicas. É um ambiente construído pelo homem que apresenta traços físicos e culturais únicos.

Para Rolim (2004), contemporaneamente, entende-se a região como um processo de construção social. A sociedade constrói um subsistema social, sendo que para tanto, promove a interação com o meio natural. Nesta concepção, a região não é apenas um espaço habitado. Ela é acima de tudo um espaço social com relações complexas entre seus habitantes. Assim, não basta que um território seja habitado para que seja considerado uma região, pois uma região congrega e permite a reprodução de vários grupos sociais, que tem como elemento comum "[...] a consciência coletiva de pertencer a um território comum específico dentro de um território nacional" (ROLIM, 2004, p. 8).

Segundo Rolim (2004), para entender uma região também é preciso informações sobre as pessoas que habitam nessa região, suas características demográficas, aspectos culturais e religiosos, padrões de consumo, nível de renda e as normas sociais e legais que regularizam as relações entre essas pessoas. Também é necessário identificar características do próprio ambiente natural, o padrão do uso da terra e de outras informações importantes para se entender a dinâmica do local analisado. As aglomerações urbanas em fronteiras nacionais são os casos mais interessantes e peculiares do fenômeno transfronteiriço, pois ao mesmo tempo em que se cria um espaço econômico comum, também se criam as barreiras para a sua integração. Isso ocorre por meio de leis que disciplinam as condições para o fluxo de pessoas e capitais, bem como as restrições para sua real efetivação. Tenta-se desenvolver uma cultura comum, ao mesmo tempo em que se tornam permanentes as diferenças culturais. As regiões transfronteiriças marcam a existência de um espaço econômico, que podem se apresentar em diferentes estágios de construção. Um fenômeno interessante que se pode observar é que, embora os espaços econômicos não reconheçam delimitações político-administrativas, eles são disciplinados por normas e regras que dificultam sua concretização, como por exemplo, a própria restrição para a livre circulação de pessoas, de bens e de serviços.

As regiões transfronteiriças surgem justamente dessa ocupação do território e das ações políticas e administrativas desenvolvidas pelos países envolvidos.

Segundo Reigado (2002), o estudo do processo pelo qual se concretiza a construção de um espaço econômico diferenciado e os obstáculos que surgem para sua concretização tornam-se elementos de grande importância para o entendimento do desenvolvimento dessas 
localidades. As barreiras impostas pelos países procuram na maioria das vezes afetar a livre circulação dos fatores de produção, e aparecem vinculadas às questões macroeconômicas dos países envolvidos (câmbio e moeda), imposições legais que inibem as migrações das pessoas e a circulação de mercadorias. Assim, um considerável problema das regiões transfronteiriças é a restrição da mobilidade entre os agentes envolvidos.

$\mathrm{Na}$ tríplice fronteira em estudo, há uma tentativa por parte dos conselhos de desenvolvimento econômico e social existentes de criar uma agenda comum de desenvolvimento, embora esses conselhos reconheçam a existência de realidades diferentes em cada país e que em cada uma das cidades há estágios diferentes de desenvolvimento socioeconômico.

A preocupação dos três conselhos de desenvolvimento econômico e social é criar estratégias conjuntas que possam potencializar as ações das empresas e de ampliar as políticas públicas que contribuam para integrar as ações econômicas das três cidades. Isso implica em aumentar a competitividade das empresas, aprimorar parcerias e promover a cultura da cooperação entre agentes sociais da região. Assim, ações que fortaleçam o turismo, o comércio e formas de associativismo e cooperativismo tornam-se essenciais para essa construção.

Nesse processo de integração e de ações focadas no desenvolvimento socioeconômico da região, a Usina Hidrelétrica de Itaipu Binacional e o Parque Tecnológico Itaipu (PTI) são importantes agentes de desenvolvimento, financiando programas e projetos que auxiliam na realização de ações de ensino, pesquisa e extensão.

A construção de um projeto integrado de desenvolvimento para a região da tríplice fronteira é uma das metas do Codefoz, do Codeleste e do Codespi. Esses conselhos de desenvolvimento econômico e social desenvolvem ações que buscam a integração e cooperação entre as três cidades. Nas observações feitas pelos especialistas entrevistados, há uma convergência de ideias em torno do fortalecimento das ações conjuntas e na elaboração de um plano de ação integrado que contemple ações de médio e longo prazo capazes de ampliar as atividades comerciais, industriais e de movimentação de pessoas na região.

Embora todas as lideranças entrevistadas tenham afirmado que há uma sinergia dos agentes locais para a efetivação desse projeto, percebe-se que as imposições legais oriundas do poder de Estado e do poder dos governos de cada cidade são obstáculos reais na concretização de um novo modelo de gestão do território.

O poder público ainda não conseguiu ser a força propulsora desse processo e os atores locais não conseguem avançar nas estratégias integradas, pois possuem limitações financeiras e até mesmo de infraestrutura para conduzirem processos complexos e que envolvem planejamento estratégico e mercadológico para a região.

Os dados da pesquisa apontam que a força propulsora na região está vinculada às ações do PTI, pois além de possuir estrutura física e humana para auxiliar no processo de desenvolvimento da região, possui ações estratégicas que podem contribuir para a constituição de um projeto integrado de desenvolvimento.

A constituição de um Arranjo Produtivo Local (APL) Transfronteiriço é uma ideia defendida pelos dirigentes dos três conselhos de desenvolvimento econômico e social, pois,

DRd - Desenvolvimento Regional em debate (ISSNe 2237-9029) 
segundo eles, a sua existência tende a melhorar a competitividade das empresas e ao mesmo tempo promover as ações de integração que são típicas nos locais onde esse tipo de arranjo se concretiza. Contudo, para constituí-lo, a participação do poder público é indispensável, considerando que além da necessidade de acordos entre os governos do Brasil, Argentina e Paraguai visando a adequar a legislação e permitir ações industriais e comerciais integradas, também é necessária a realização de investimentos em infraestrutura, logística, sistemas de produção, comercialização e na qualificação dos agentes envolvidos. Essas ações teriam como foco principal as micro e pequenas empresas das três cidades, que caso agrupadas num APL transfronteiriço, poderiam ter acesso às novas tecnologias de produção e gestão e aos processos mercadológicos mais eficientes.

A existência de um APL transfronteiriço na região também conta com uma oportunidade de mercado que é uma peculiaridade da região, ou seja, a tríplice fronteira analisada já é um dos principais locais comerciais do planeta e, portanto, há um público alvo potencial que se desloca para fazer compras na região. $\mathrm{Na}$ opinião dos especialistas entrevistados, além de atender a esse público, os produtos fabricados num APL Transfronteiriço poderiam também ser vendidos para outras regiões. Seria também uma forma de focar o potencial endógeno existente.

O presidente do Codespi defende a construção de um projeto integrado de desenvolvimento, mas aponta que há enormes dificuldades para tanto, até mesmo em relação ao próprio relacionamento social e cultural entre argentinos, brasileiros e paraguaios, citando como exemplo uma grande rivalidade entre os empresários das três cidades, que ainda não desenvolveram a cultura da cooperação empresarial.

$\mathrm{Na}$ busca da construção de um projeto integrado de desenvolvimento e da consolidação de APLs transfronteiriços, a Itaipu Binacional e o PTI exercem papel relevante. As parcerias firmadas com universidades, como a Universidade Estadual do Oeste do Paraná (Unioeste), Universidade Federal da Integração Latino-Americana (Unila), Universidade de São Paulo (USP), Pontifícia Universidade Católica (PUC), e com o Instituto de Tecnologia Aplicada e Inovação (Itaí), auxiliaram na consolidação de um espaço de inovação capaz de contribuir com o modelo de desenvolvimento territorial proposto pela Itaipu, que tem como base ações inovadoras e empreendedoras, bem como, princípios éticos, cooperação, integração e solidariedade. Essas ações estão alinhadas com os objetivos dos três conselhos de desenvolvimento econômico e social, pois buscam promover o desenvolvimento científico e tecnológico do território, melhorar a qualificação das pessoas e contribuir para o fortalecimento das atividades produtivas desenvolvidas na região.

A oferta de cursos de atualização pelo PTI, bem como de cursos de graduação e de pós-graduação em nível de especialização, mestrado e doutorado também são elementos importantes para o planejamento da constituição de APLs e do fortalecimento de empresas no local. No âmbito da pesquisa, o PTI possui uma infraestrutura de alto padrão e uma equipe qualificada de pesquisadores e técnicos para atuar na busca de soluções tecnológicas inovadoras em diversa áreas, como a bioengenharia, energia alternativa e agronegócio.

A concepção de um projeto integrado de desenvolvimento perpassa pelo debate sobre o uso compartilhado do território e do entendimento de que a região transfronteiriça deveria ser um local de livre acesso entre os moradores das três cidades e de livre comércio, podendo atender turistas e moradores de Foz do Iguaçu, Puerto Iguazú e Ciudad del Este. 
Como argumenta Reigado (2002), as barreiras impostas pelos países procuram na maioria das vezes afetar a livre circulação dos fatores de produção e também imposições legais que inibem as migrações das pessoas e a circulação de mercadorias. Ou seja, indica que um dos problemas das regiões transfronteiriças é a restrição da mobilidade entre os agentes envolvidos.

Rolim (2004), também chama a atenção para as regiões transfronteiriças, comentando que os países tentam construir um espaço econômico comum, porém ao mesmo tempo criam barreiras que dificultam sua integração.

Como se constatou por meio das entrevistas, isso ocorre na região em estudo, pois conforme os dados obtidos com os especialistas e documentos oficiais sobre as políticas públicas na tríplice fronteira, observa-se que embora haja um discurso defendendo a integração, no cotidiano da vida da fronteira há graves restrições a essa integração. A saúde é um dos casos a serem analisados. Cidadãos paraguaios e argentinos precisam com frequência dos serviços de saúde ofertados em Foz do Iguaçu, mas nem sempre conseguem acesso. Na entrevista com os diretores do Codeleste essa necessidade foi destacada e foi mencionado que para muitos cidadãos paraguaios o atendimento do Sistema único de Saúde (SUS) no Brasil é a única alternativa em certas situações de enfermidade. São pessoas que devido à sua vulnerabilidade social não podem pagar por serviços particulares, tanto no Brasil como no Paraguai. Além disso, a precariedade dos serviços de saúde no Paraguai faz com que apenas na capital Assunção haja atendimento de qualidade para alguns tipos de tratamentos médicos. Além dos custos dos serviços, para a população pobre o deslocamento de aproximadamente $300 \mathrm{~km}$ de Ciudad del Este até a capital é algo quase impossível. Isso gera conflitos nas unidades de saúde e nos hospitais de Foz do Iguaçu, que não têm capacidade para atender a demanda, mas que também não podem negar atendimento por questões humanitárias e sociais. No ano de 2017, a Secretaria da Saúde da Prefeitura de Foz do Iguaçu criticou duramente essa situação e defendeu que o atendimento para paraguaios e argentinos deveriam ser realizados apenas em caso de emergência, e não de forma frequente como estava ocorrendo.

Quando entendemos o conceito de uma região transfronteiriça, atitudes como essas no mínimo causam espanto e mostram que o projeto integrado de desenvolvimento ainda está muito longe de se tornar realidade. É sabido que os recursos para a saúde no Brasil são insuficientes para atender às demandas da população e que o cenário ideal seria ampliar as políticas públicas de saúde no local e encontrar novas soluções para atender às demandas de brasileiros, argentinos e paraguaios, como por exemplo, a criação de um território sanitário comum, com investimentos do poder público de Ciudad del Este, Puerto Iguazú e Foz do Iguaçu. Essa seria uma alternativa que está alinhada com a proposta de um projeto integrado de desenvolvimento, e que poderia romper com a situação constrangedora imposta pela presença da fronteira e pela falta de percepção e sensibilidade social dos agentes públicos das três cidades.

O PTI também realizou ações importantes para ampliar os programas de saúde na região, principalmente o Grupo de Trabalho para Integração das Ações de Saúde na Área de Influência da Itaipu (GT Itaipu-Saúde), que desenvolveu ações de integração e de cooperação entre Brasil, Argentina e Paraguai. 
No aspecto educacional, os representantes do Codefoz, Codespi, Codeleste e do Sindicato dos Comerciários de Foz do Iguaçu (Sincof), citam que é necessário compartilhar os serviços de educação entre as três cidades, oportunizando o acesso da sua população ao ensino disponibilizado do outro lado da fronteira, contribuindo para a geração de empregos e fortalecimento do comércio.

Quanto às ações empreendedoras, as entrevistas indicaram que tais iniciativas na região ocorreram de forma isolada no período e não fizeram parte de um agenda coletiva e de um planejamento estratégico orientado para a consolidação de um projeto integrado de desenvolvimento. As lideranças do Codeleste afirmaram que no período de 2007 a 2015 não houve políticas públicas realizadas pelo Paraguai para incentivar a criação de novas empresas e mesmo de apoiar sua expansão. $\mathrm{O}$ acesso ao crédito e a programas governamentais focados na melhoria do processo de gestão também não foram observados. O período de 2007 a 2015 foi selecionado para análise pelo fato de que foi neste espaço temporal que foram implantadas no Brasil as principais políticas públicas para a faixa de fronteira.

A diretoria do Codeleste também citou que as iniciativas de organização e de aperfeiçoamento do tecido empresarial de Ciudad del Este esteve neste período vinculado às ações dos atores sociais que sempre se preocuparam com a realização de ações de conscientização sobre a importância da colaboração para o sucesso dos empreendimentos, mas que nem todos os empresários concordam com essa ideia, sendo que é mais comum as empresas optarem pela competição do que pela colaboração. Na entrevista, os entrevistados enalteceram o papel do Codefoz e do Sebrae no processo de conscientização e de aprimoramento da gestão dos empreendimentos.

No Codespi, há também a percepção de que não houve, no período de 2007 a 2015 , ações integradas que contribuíram para alavancar as iniciativas empreendedoras na região.

Puerto Iguazú é uma cidade que possui um grande potencial turístico, que além das Cataratas e do Cassino, conta com bares, restaurantes, hotéis e um comércio diversificado, tendo potencial para interagir com Foz do Iguaçu e Ciudad Del Leste de forma harmônica. O presidente do Codespi enfatizou que há na cidade um pequeno grupo de grandes empresários que trabalham contra a ideia de uma maior integração e que isso dificulta a própria conscientização da população local sobre a importância de se criar uma região transfronteiriça com uso compartilhado do território.

Em Foz do Iguaçu, o Codefoz e o Sebrae são entidades que atuam diretamente na tentativa de promover ações que contribuam para a efetivação de ações empreendedoras na região. Nesse processo, a Itaipu Binacional e o PTI também realizam ações visando dar apoio às inciativas empreendedoras, como por exemplo, o Programa Regional de Formação para o Desenvolvimento Econômico Local com Inclusão Social, cujo objetivo é de promover a qualificação dos atores locais para que possam desenvolver e executar projetos cooperados. Trata-se de um projeto que envolve universidades, associações comerciais, entidades de classes, prefeituras, e associações de produtores.

$\mathrm{Na}$ região transfronteiriça analisada, conforme a interpretação dos elementos do Hexágono do Desenvolvimento Regional, os atores individuais são na maioria representados por famílias tradicionais do local, que exercem há muito tempo influência política e

DRd - Desenvolvimento Regional em debate (ISSNe 2237-9029) 
econômica no processo de desenvolvimento regional. Esse grupo é composto por pessoas que acabam interferindo na forma do desenvolvimento local.

Num estudo realizado por Nascimento (2010), os principais grupos políticos ou pessoas mais influentes de Foz do Iguaçu, Ciudad del Este e Puerto Iguazú foram identificados. O Quadro 1 indica quais são esses grupos e pessoas.

Quadro 1 - Principais grupos políticos ou pessoas mais influentes em Foz do Iguaçu, Ciudad del Este e Puerto Iguazú.

\begin{tabular}{|l|l|l|}
\hline \multicolumn{1}{|c|}{ FOZ DO IGUAÇU } & \multicolumn{1}{|c|}{ CIUDAD DEL ESTE } & \multicolumn{1}{c|}{ PUERTO IGUAZÚ } \\
\hline Paulo Mac Donald Ghizi, & Sandra Mac Leod Zacarias, Ernesto \\
Dobrandino Gustavo da Silva, & Javier Zacarias Irún, Nelson Dário \\
Jorge Miguel Samek, Reni Clóvis & Aguinagalde, Adolfo Raú L. & Consul da Argentina, Timoteo \\
de Souza Pereira, Carlos Juliano & Gimenes, Romildo Antonio de & que foi prefeito de Purto \\
Budel, Francisco Lacerda & Iguazú e Deputado, e Cláudio Raúl \\
Brasileiro, Família Rafagnin, José & Souza Maia, Joaquim Lopes & Filippa, que foi prefeito da cidade. \\
Carlos Neves da Silva, Fernando & Hammoud, Kenny Yuen. Neste & \\
Lúcio Giacobo, Gessani da Silva, & grupo há políticos e grandes \\
Joane Vilel Pinto, Luís Augusto & empresários, como por exemplo, & \\
Pinho de Queiroga, Sérgio Leonel & Charif Hammoud que é diretor do & \\
Beltrame, Sérgio Spada. & grupo Monalisa. & \\
\hline
\end{tabular}

Fonte: Elaborado pelos autores com base na pesquisa de Nascimento (2010, p. 151-180).

Essas pessoas exercem alta influência na condução do processo político de suas cidades, sendo que algumas já exerceram cargos públicos e influenciaram as ações econômicas da região. Exercem também influência no modelo de desenvolvimento da cidade e nos tipos de empreendimentos que são apoiados ou não, pelo poder público. São representantes de famílias tradicionais que exercem influência econômica, financeira e política, contribuindo ou interferindo no processo de desenvolvimento conforme seus próprios interesses.

Souza (2006), cita que os interesses de grupos influenciam as decisões dos governos e nas ações que implicam em consequências para a economia e para a sociedade, ou seja, os governos traduzem suas plataformas eleitorais em programas e ações concretas que na prática beneficiam grupos específicos. Considerando que os recursos públicos existentes são insuficientes para atender todas as demandas da sociedade, os bens e serviços públicos transformam-se em motivo de disputa. Essa não é uma realidade apenas da região da tríplice fronteira, mas também de outras regiões do estado do Paraná e do Brasil. Essa influência se dá na forma de incentivos à constituição de novas empresas, do apoio fiscal e financeiro aos novos empreendimentos ou no financiamento público para as empresas existentes. Esses atores representam o poder político das últimas décadas, são pessoas que foram eleitas para cargos públicos, como prefeitos e deputados, cônsul e até mesmo governador. Portanto, o modelo de desenvolvimento defendido por esses grupos parece ter sido um modelo concentrador e excludente, não apoiando as ações de parcerias e incentivo a micro e pequenos empresários, considerando que esses grupos possuem grandes empresas e disputam a mesma fatia de mercado das micro e pequenas empresas.

DRd - Desenvolvimento Regional em debate (ISSNe 2237-9029) 
Quanto aos atores coorporativos, Nascimento (2010, p. 153), apontou que em Foz do Iguaçu há a presença de sindicatos, associações e entidades organizadas que exercem uma forte atuação. Os principais sindicatos em Foz do Iguaçu são: Sindicato dos Empregados no Comércio de Foz do Iguaçu (Sinecofi), Sindicato dos Trabalhadores em Turismo e Hospitalidade de Foz do Iguaçu (STTHFI), Sindicato de Hotéis Restaurantes Bares e Similares de Foz do Iguaçu; Conselho Municipal de Turismo (COMTUR), Sindicato das Empresas de Turismo de Foz do Iguaçu; Sindicato Patronal do Comércio Varejista de Foz do Iguaçu; Sindicato dos Eletricitários, Sindicato dos Rodoviários, Sindicato dos Empregados em Empresas de Asseio e Conservação, Áreas verdes, Áreas Urbanas e Meio Ambiente de Foz do Iguaçu (SIEMACO). No campo empresarial, o destaque é para as atividades realizadas pela Associação Comercial e Empresarial de Foz do Iguaçu (ACIF) e pela Federação do Comércio do Paraná (Fecomércio-PR).

Em Ciudad del Este, conforme Nascimento (2010, p. 191), há o Sindicato dos Choferes, Sindicato dos Trabalhadores da Itaipu Binacional (STEIBI) e Sindicato dos Engenheiros. Na pesquisa de Nascimento, em Puerto Iguazú não foram identificados sindicatos.

Portanto, na região em análise, os atores coorporativos são representados pelos sindicatos e associações citadas e pelos conselhos de desenvolvimento econômico e social existentes, ou seja, o Codefoz, Codespi e Codeleste. Esses atores exercem influência junto às categorias de trabalhadores e de empresários que representam, mas ainda não conseguem ter força significativa na condução e na aprovação das políticas de desenvolvimento regional.

Os atores coorporativos da região representam uma força oposta aos atores individuais, atuando na construção de espaços empresariais que valorizam a colaboração, as parcerias e a socialização do conhecimento e fortalecimento de políticas sociais. São entidades que acreditam no potencial endógeno, no poder da organização social e na elaboração de uma agenda pautada numa cultura empresarial de cooperação.

Os dados da pesquisa indicam que isso ainda é algo em estágio inicial, que ainda há muito a ser feito e que os resultados dos esforços dos conselhos de desenvolvimento econômico e social ainda são modestos. Contudo, não se pode negar a importância desse movimento a médio e a longo prazo. As informações obtidas pelas entrevistas apontam para uma região que ainda não tem tradição na cultura cooperativa e solidária, pois não há ações que valorizem o associativismo, o cooperativismo e a criação de APLs. Isso reforça a natureza da cultura competitiva/individualista da região, que em última análise, remete às ações dos atores individuais que exercem o poder econômico e político no local.

Portanto, há indicativos de que ainda não há força política suficiente na região para romper com o predomínio da cultura competitiva/individualista, que avance na consolidação de um novo modelo de desenvolvimento do território e que crie condições efetivas para o crescimento da cultura da cooperação e da socialização do conhecimento empresarial. Essa mudança de paradigma pode resultar num processo de desenvolvimento e de equidade do local.

As conclusões oriundas das entrevistas também confirmam essa tendência. Embora o Sebrae e o PTI tenham desenvolvido ações que visam ao fortalecimento das relações de parcerias das empresas no processo produtivo e de comercialização, isso ainda não foi

DRd - Desenvolvimento Regional em debate (ISSNe 2237-9029) 
suficiente para se criar a cultura cooperativa solidária. O preconceito que empresários brasileiros demonstram com relação às empresas paraguaias também indica que a cultura competitiva/individualista prevalece. Essas situações foram destacadas tanto pelo presidente do Codespi como pelos presidentes do Codeleste e do Codefoz. Embora esses conselhos de desenvolvimento econômico e social tenham clareza da necessidade do desenvolvimento pautado na cooperação e na promoção de uma cultura que seja capaz de gerar desenvolvimento e equidade, as ações das empresas existentes na localidade são pautadas no individualismo e na ausência de um projeto coletivo e colaborativo.

Na região da tríplice fronteira há também a presença de importantes recursos naturais e de equipamentos de infraestrutura. É uma região que se destaca no cenário mundial por suas belezas naturais e pelas grandes obras de infraestrutura, como a Itaipu Binacional, o PTI, as Cataratas do Iguaçu, Parque Nacional do Iguaçu, Lago de Itaipu, Ponte Internacional da Amizade e Ponte Presidente Tancredo Neves, além de rodovias de acesso como a BR 277, Aeroporto Internacional de Foz do Iguaçu/Cataratas, Rodoviária Internacional e terminais de ônibus urbanos, além de diversos atrativos turísticos representados por parques, museus, igrejas, templos, feiras, centros gastronômicos e centros culturais. Considerando a presença de universidades, centros de pesquisas e principalmente das ações do PTI e de instituições como o Sebrae, há indícios de que existe quantidade e qualidade dos recursos humanos na região. Em Ciudad del Este e Puerto Iguazú essa realidade é um pouco diferente. No que se refere aos recursos psicossociais, observa-se que os Codefoz, Codespi e Codeleste fomentam a autoconfiança coletiva e demonstram perseverança em suas ações. O PTI também exerce esse papel, realizando ações que contribuem para o aprimoramento dos recursos humanos da região, por meio de ações de ensino, pesquisa e extensão. Essas ações produzem conhecimento e permitem que esse conhecimento seja compartilhado entre os recursos humanos envolvidos. Nascimento (2010), cita que em Ciudad del Este há grupos econômicos e empresas que dominam o mercado, como demonstra o Quadro 2.

Quadro 2 - Principais grupos econômicos e empresas da tríplice fronteira

\begin{tabular}{|l|l|l|}
\hline \multicolumn{1}{|c|}{ FOZ DO IGUAÇU } & \multicolumn{1}{c|}{ CIUDAD DEL LESTE } & \multicolumn{1}{c|}{ PUERTO IGUAZÚ } \\
\hline Itaipu Binacional, Grupo & Shopping Monalisa, Shopping & Dutty Free Shop, Hotel Casino \\
Panorama, Grupo Irmãos Muffato, & Americana, Grupo Nave Shop, & Iguazú, Sheraton Iguazú Resort \& \\
Grupo Educacional Dinâmica, & Casa China, Família Jebai, La & Spa, Despachante Henrique \\
Grupo Irmãos Rafain, Cataratas & Petisquera, SAX - Fenícia Groups, & Scherer, Rede de Postos. \\
S/A, Shopping JL, Transporte & Mercosur Câmbios S/A, Casa & \\
Coletivo de Foz do Iguaçu, & Nippon, Master Informática, \\
Bourbon Hotéis e Resorts, Calce & Shopping Mina Índia, Shopping del \\
Pague, CVC Turismo, Difoz & Este, Agrotec S/A - Insumos, \\
Escapamentos, Grupo Uniamérica, & Câmara de Comércio de \\
Hotel Mabu, Loja Gaúcha, Santi & Tecnologia da Informação (CCTI), \\
Móveis, Super Max & Supermercado Granvia, Compubras & \\
(Supermercados), TSA & Informática. & \\
Transportadora. & & \\
\hline
\end{tabular}

Fonte: Elaborado pelos autores com base na pesquisa de NASCIMENTO (2010, p.189).

Essas empresas e grupos econômicos possuem uma grande tradição nas atividades comerciais e representam famílias tradicionais de origem brasileira, chinesa, coreana e árabe.

DRd - Desenvolvimento Regional em debate (ISSNe 2237-9029) 
As entrevistas realizadas com os especialistas apontaram para uma deficiência dos procedimentos por parte da gestão do governo territorial. Na análise dos especialistas, há um grande despreparo ou falta de interesse dos gestores públicos tanto de Foz do Iguaçu, Ciudad del Est e Puerto Iguazú em exercer liderança e tomar decisões que contribuam para a formação de um projeto integrado de desenvolvimento. Observou-se que independentemente do tamanho das empresas e do seu volume de vendas, tanto as microempresas como as grandes corporações, não possuem uma estratégia compartilhada de desenvolvimento. Suas ações são isoladas e segundo os entrevistados, não há um projeto comum, um planejamento estratégico que valorize a colaboração e a realização de ações conjuntas para o desenvolvimento da região.

Na região em análise, há indícios de ser um local de produção de conhecimento que ocorre por meio das universidades, institutos de pesquisa e extensão e das ações do PTI. Percebe-se que os três conselhos de desenvolvimento econômico e social tentam criar mecanismos para que haja uma maior socialização das informações, objetivando difundir o conhecimento gerado para todas as cidades.

A região Oeste do Paraná, na qual está localizada a cidade de Foz do Iguaçu, é uma região de grande produção agroindustrial e que exporta essa produção para outras regiões do Brasil e para outros países. Foz do Iguaçu, devido à sua pequena área destinada à produção agrícola, não se enquadra no perfil dos demais municípios do Oeste do Paraná. Portanto, o motor da economia de Foz do Iguaçu, de Ciudad del Este e de Puerto Iguazú são as atividades comerciais, prestação de serviços, turismo e produção industrial.

As mercadorias adquiridas na tríplice fronteira são comercializadas em diversos estados brasileiros. Segundo Nascimento (2010, p. 46-47), Foz do Iguaçu é um local geoestratégico e que mantém laços econômicos com o Oeste Catarinense, Oeste Gaúcho, Macrorregião Centro-Oeste, principalmente com o Mato Grosso do Sul, e com a Macrorregião Sudeste, principalmente com São Paulo. As mercadorias são escoadas principalmente pelas Rodovias BR 467, BR 163 e BR 277, e também pelas Rodovias Paranaenses (PRs) que embora apresentem menor relevância devido ao menor volume de circulação de mercadorias, não deixam de ter importância no processo comercialização. Essas rodovias asseguram à região um importante desempenho nas relações internacionais entre as cidades que compõem a tríplice fronteira e permitem o fortalecimento dos vínculos comerciais com os demais estados brasileiros e com o Mercosul.

A cidade Argentina de Puerto Iguazú é uma cidade preparada para atender aos cidadãos argentinos e turistas brasileiros que a visitam. Em Ciudad del Este, as lojas de pequeno porte e barracas estão organizadas para atender sacoleiros, pequenos empresários e até mesmo contrabandistas, embora haja também turistas que vão à Ciudad del Este para conhecê-la e para fazer compras pessoais. Porém, em Ciudad del Este, há também grandes grupos empresariais que possuem condições de atender em larga escala e o fazem de forma profissional. São empresas de grande estrutura econômica e financeira e que estão conectas aos circuitos globais da economia.

Em Foz do Iguaçu há o predomínio das atividades de turismo, mas as atividades comerciais e industriais também são relevantes. Percebe-se que muitos turistas vão à Foz do Iguaçu com o intuito de conhecer seus pontos turísticos, mas também para fazer compras no

DRd - Desenvolvimento Regional em debate (ISSNe 2237-9029) 
Paraguai e conhecer Puerto Iguazú. Assim, a realidade das três cidades demonstra peculiaridades no uso e ocupação do solo e no tipo de produtos comercializados.

\section{CONSIDERAÇÕES FINAIS}

A realidade empresarial das três cidades da tríplice fronteira é bastante diferente. Foz do Iguaçu apresenta um tecido empresarial fortalecido, com empresas que usam tecnologia da informação, métodos de produção aprimorados e estratégias mercadológicas. Isso contribuiu para que no período de 2007 a 2015 a cidade atingisse bons índices de desenvolvimento, mantendo-se conectada a outros centros comerciais e se tornando uma importante cidade do Estado do Paraná. Conforme dados do SISTEMA FIRJAN (2017), a partir de 2007 houve uma constante melhora nos índices FIRJAN de Desenvolvimento Municipal (IFDHM) em Foz do Iguaçu, sendo que no ano citado estava em 0,6736 , ou seja, classificado como desenvolvimento moderado, e em 2013 chegou a 0,8232, sendo classificado como alto desenvolvimento. Esse dado mostra que no período houve uma melhoria na qualidade de vida dos moradores de Foz do Iguaçu e elevação na renda, no acesso aos serviços de saúde e de educação dessa população.

De acordo com o ATLAS DO DESENVOLVIMENTO HUMANO (2017), entre 1991 e 2000, a população do município de Foz do Iguaçu cresceu a uma taxa média anual de $3,47 \%$. No Brasil, a taxa de crescimento neste período foi de 1,63\%. A taxa de urbanização do município passou de $98,03 \%$ para $99,22 \%$. Houve também um crescimento acentuado do PIB no período de 2007 a 2014, tendo um aumento de 56,57\% entre 2007 e 2013 . No ano de 2014, houve uma redução de 3,83\%, em relação aos valores de 2013, mas se compararmos os valores de 2007 com os valores de 2014, teremos também um aumento de 50,79\%. A evolução da desigualdade de renda nesses dois períodos pode ser descrita pelo Índice de Gini, que foi de 0,57 em 1991 e manteve-se no mesmo patamar de 0,57 em 2000, e passou para 0,53 em 2010. Embora discreta, houve uma evolução positiva. No período houve também uma redução do percentual de pessoas extremamente pobres e de pessoas pobres, indicando que a região conseguiu desenvolver ações que atenderam a faixa da população que mais necessitava de acesso aos serviços públicos básicos e de oportunidades de trabalho e renda. A taxa de desocupação (ou seja, o percentual da população economicamente ativa que estava desocupada) passou de 14,56\% em 2000 para 6,47\% em 2010. Esses dados demonstram que no período de 2007 a 2015 houve melhoras nos índices de desenvolvimento econômico e social.

Em Puerto_Iguazú a maioria das empresas é de pequeno porte e no aspecto industrial a cidade é fragilizada, sendo essa uma das preocupações apontadas nas entrevistas com os especialistas. A falta de dados estatísticos e de indicadores econômicos e sociais impedem que se faça um diagnóstico exato da situação industrial e comercial do local.

Em Ciudad del Leste há um comércio fortalecido e conectado com outras regiões do Paraguai, Argentina, Brasil e de outros países. A economia é controlada por grandes grupos empresariais e também há um grande volume de micro e pequenas empresas que atuam, principalmente no mercado de rua. Os grandes grupos e empresas têm seus maiores expoentes 
nos grandes Shoppings e redes de lojas tradicionais e das principais empresas que dominam o mercado paraguaio.

Os elementos que compõem o Hexágono do Desenvolvimento Regional, precisam interagir para que se consiga promover o desenvolvimento regional. Com base nos dados apresentados, percebe-se que embora na região todas as vértices do hexágono estejam presentes, ainda não há uma articulação consistente entre eles capaz de produzir os níveis de desenvolvimento desejado, havendo apenas uma articulação difusa e aleatória, insuficiente para promover o desenvolvimento e contribuir na constituição de um projeto integrado de desenvolvimento para a região.

Os atores sociais exercem um relevante papel na região, em especial os conselhos de desenvolvimento econômico e social, contudo não há uma articulação com os atores políticos, com os sindicatos e com a massa empresarial. Isso faz com que as ações empreendedoras sejam isoladas e produzam efeitos abaixo do desejado. Essa falta de sintonia das ações impede parcerias estratégicas entre os três conselhos de desenvolvimento econômico e social com o PTI e com a Usina Hidrelétrica de Itaipu. Essas parcerias poderiam ser a base para um Projeto de Desenvolvimento Integrado, dado a estrutura física, financeira e qualidade dos recursos humanos existentes nessas entidades. Também seria possível encontrar formas de transformar a cultura competitiva/individualista predominante no local em cultura cooperativa/solidária, oportunizando a consolidação de um modelo capaz gerar não apenas crescimento econômico, mas também, um verdadeiro processo de desenvolvimento pautado na equidade e na produção de autorreferência do seu próprio território.

Os recursos existentes no local permitem a consolidação de um projeto integrado de desenvolvimento, destacando-se os recursos naturais, os recursos humanos, recursos psicossociais e recursos de conhecimento. Há, portanto, um conjunto de elementos que são favoráveis ao desenvolvimento, mas que não estão interagindo de forma planejada com as principais instituições existentes. Essa falta de interação prejudica a flexibilidade, velocidade e capacidades dessas organizações em estabelecer articulações com outras instituições e configurar arranjos empresarias estratégicos que venham a beneficiar as três cidades. Para que isso ocorra, essas instituições precisam ter procedimentos adequados, principalmente no que se refere à natureza da gestão do governo territorial, marcado não apenas pelo uso de tecnologias e sistema de informação, mas principalmente pelo conjunto de ações que representam o exercício da autoridade, liderança, capacidade de tomadas de decisão e de respeito aos princípios democráticos. Ainda não é o que ocorre na tríplice fronteira e no seu entorno. O entorno, de acordo com o Hexágono do Desenvolvimento Regional, é constituído por tudo que é externo à região e é configurado pela multiplicidade de organismos, sobre os quais a região tem a capacidade de influência, mas não tem controle desses organismos. É o mercado em sentido lato, o Estado e as Relações Internacionais.

Os dados obtidos indicam que ainda não há um projeto integrado de desenvolvimento para a região e que os esforços do Codefoz, Codespi e Codeleste ainda não são suficientes para construir um projeto coletivo. Não falta comprometimento dos atores sociais, mas para que esse projeto se consolide é necessário também a presença de políticas públicas consistentes, investimentos em infraestrutura e a vontade política em elaborar normas, regulamentos e leis específicas para a região, o que ainda não ocorre no local. 
Portanto, na tríplice fronteira estudada não se pode afirmar que há um projeto político integrado, ao contrário, o que há é apenas a caixa preta citada por Boisier (1996), ou seja, não se sabe o que acontecerá nos próximos anos em termos de desenvolvimento regional.

\section{REFERÊNCIAS}

\section{ATLAS DO DESENVOLVIMENTO HUMANO NO BRASIL. Perfil Foz do Iguaçu.}

Disponível em: < http://www. atlasbrasil.org.br/2013/pt/perfil_m/foz-do-iguacu_pr.> Acesso em: 10 ago. 2017.

BOISIER, S. Em busca do esquivo desenvolvimento regional: entre a caixa-preta e o projeto político. Revista Planejamento e Políticas Públicas, Brasília, IPEA nº 13, jun. de 1996. Disponível em: <http://www.ipea.gov.br/>. Acesso em: 17 mar. 2017.

BRASIL. Ministério da Integração Nacional. Política nacional de desenvolvimento regional (PNDR). Brasília, DF: Secretaria de Programas Regionais, 2015.

CARDIN, E. G. Os trabalhadores das vias públicas de Ciudad del Este: considerações preliminares sobre os mesiteros e suas associações. Revista História em Reflexão, Dourados. v. 4, n. 7, p. 01-17, jan./jun. 2010.

CATTA, L. E. P. O cotidiano de uma fronteira: a perversidade da modernidade. Cascavel: EDUNIOSTE, 2002.

CORRÊA, R.L. Região e organização espacial. 7.ed. São Paulo: Ática, 2000.

CURY, M. J. F. Territorialidade transfronteiriça do Iguassu (TTI). Interconexões, interdependências e interpenetrações nas cidades da tríplice fronteira - Foz do Iguaçu (BR), Ciudad del Este (PY) e Puerto Iguazú (AR). Tese (Doutorado em Geografia) - Universidade Federal do Paraná, Curitiba, 2010.

HAESBAERT, R. Regiões transfronteiriças e migração brasileira em países do Mercosul. Rio de Janeiro: Bertrand Brasil, 2013.

O mito da desterritorialização: do fim dos territórios à multiterritorialidade. Rio de Janeiro: Bertrand Brasil, 2004.

MATTOS, C. M. Geopolítica e teoria de fronteiras. Rio de Janeiro: BIBLIEX. 1990.

MOURA FILHO, J. L. Multiterritorialidade em regiões transfronteiriças: estudo de duas cidades gêmeas na fronteira brasil/Uruguai. 2010. Tese (Doutorado em Desenvolvimento Regional) - Programa de Pós-Graduação em Desenvolvimento Regional. Universidade de Santa Cruz do Sul, Santa Cruz do Sul, 2010.

MYSKIW, A. M. A fronteira como destino de viagem: a colônia militar de Foz do Iguaçu (1888-1907). Guarapuava: Unicentro, 2011. 
NASCIMENTO, W. C. As relações de poder no contexto político econômico de Foz do Iguaçu PR. 232f. Dissertação (Mestrado em Geografia). Programa de Pós-Graduação. Departamento de Geografia do Centro de Ciências Humanas, Letras e Artes. Universidade Estadual de Maringá, Maringá, 2010.

POLON, L. C. K. A fronteira do consumo: relações transfronteiriças entre Foz do Iguaçu (BR) e Ciudad del Este (PY). Dissertação (Mestrado em Geografia) - Programa de PósGraduação. Universidade Estadual do Oeste do Paraná, Marechal Cândido Rondon, 2014.

REIGADO, F. M. O Desenvolvimento regional transfronteiriço. In: COSTA, J. S.;

NIJKAMP, P. (org.). Compendio de Economia Regional. Lisboa: Principia, 2002, p. 555 580 .

ROLIM, F. C. Como analisar as regiões transfronteiriças: esboço de um enquadramento teórico-metodológico a partir de caso de Foz do Iguaçu. Trabalho apresentado na III ECOPAR, Encontro de Economia Paranaense, Anais..., Londrina, 2004.

SACHS, I. Ecodesenvolvimento: crescimento sem destruir. São Paulo: Vértice, 1986.

SANTOS, M. A natureza do espaço. São Paulo: HUCITEC, 1996.

Por uma geografia nova. São Paulo: Hucitec, Edusp, 1978.

Espaço e método. São Paulo: Nobel, 1985. $\overline{\mathrm{USP}, 2} 2006$.

A natureza do espaço: técnica e tempo, razão e emoção. 4. ed. 2. reimpr São Paulo:

SISTEMA FIRJAN. Índice Firjan de Desenvolvimento Municipal (IFDM). Disponível em: $<$ http://www.firjan.com.br/ifdm/consulta-ao-indice/ifdm-indice-firjan-de-desenvolvimentomunicipal-resultado.htm?UF=PR\&IdCidade $>$. Acesso em: 05 jun. 2017.

SOUZA, C. Políticas públicas: uma revisão da literatura. Sociologias, Porto Alegre, a. 8, n. 16, p. 20-45, jul./dez. 2006.

Artigo recebido em: 07/11/2018

Artigo aprovado em: 11/03/2019

Artigo publicado em: 22/03/2019 